\title{
Salgın Hastalıklardan Koruma ve Kontrol Önlemleri, COVID-19 Pandemisi ile Mücadele ve Yaşanan Güçlükler $\infty$
}

\author{
Hayriye ÜNLÜ ${ }^{1}$, Emine ÇiçEK ${ }^{2}$
}

\section{öz}

Küreselleşmeyle birlikte, bir ülkede ortaya çıkan bulaşııı hastalığın hızla başka bir ülkeye yayılma olasııı̆ı̆ artmaktadır. Bu küresel artış küresel bir dayanışmayı gerektirmektedir. Küresel salgınlar; mortalitede artışa sebep olmakla birlikte, sosyal ve siyasi yapıyı bozmakta, ekonomiyi olumsuz etkilemekte, olumsuz psikolojik etkilere yol açmakta ve sağlık sistemini derinden sarsmaktadır. Salgının erken tespit edilmesi ve müdahale önlemlerinin hızlı bir şekilde başlatılması, salgını kontrol etme imkanını arttırmaktadır. Koruma ve kontrol önlemleri kapsamında salgının özelliğine göre alınacak tedbirler: İlgili sektörlerle iş birliğinin yapılması, risk oluşturan etkenlerin (kontamine su kaynaklarının kullanımının engellenmesi ve suyun klorlanması) uzaklaştırılması, hasta izolasyonu, temaslılara müdahale edilmesi, riskli grupların aşılanması, sağlık personelinin eğitimi ve halk sağlığı eğitimini kapsamaktadır. Günümüzde COVID-19 enfeksiyonu dünya çapında bir salgın olup halihazırda geliştirilmiş bir tedavi yöntemi veya aşısı bulunmamaktadır, bu nedenle bulaşmayı azaltmak için alınan önlemler ve kontrol stratejileri halk sağlığı önlemlerine dayanmaktadır. Topluma yavaş / geç bilgi verilmesi, korunmaya ilişkin önlemler hakkında bilgi ve farkındalık eksikliği, söylentileri durdurmak için önlem alınmaması, sağlık yetkililerine güvenin azalması, sağlık çalışanları arasında uygun enfeksiyon önleme ve kontrol önlemlerinin uygulanmaması ve kültürel farklılıklar COVID19 ile mücadelede engelleri oluşturmaktadır.

Bu makalede salgınla mücadele stratejilerine ve günümüz salgını olan COVID-19'un kontrol yöntemlerine ve salgınlarla mücadeleyi etkileyen engellere değinilmiştir.

Anahtar kelimeler: COVID-19, kontrol, önlem, salgınlar

\begin{abstract}
Protection and Control Measures from Epidemic Diseases, Combating COVID-19 Pandemic and Difficulties Experienced

The possibility of an infectious disease emerging in one country to rapidly spread to another country increases with globalization. The global increase in infectious diseases requires international solidarity against these diseases. Although global epidemics cause an increase in mortality, they disrupt the social and political structure, negatively affect the economy, cause negative psychological effects and deeply shake the health system. Early detection of the outbreak and rapid initiation of intervention measures increase the ability to control the epidemic.

Measures to be taken according to the nature of the epidemic within the scope of protection and control measures include cooperation with relevant sectors, removal of risk factors (prevention of the use of contaminated water resources and chlorination of water) patient isolation, intervention to contacts, vaccination of risky groups, training of healthcare personnel and public health education. Nowadays, COVID-19 infection is a worldwide epidemic, and there is currently no improved treatment method or vaccine, so measures and control strategies to reduce transmission are based on public health measures. Slow/delayed provision of information to the community, lack of knowledge and awareness of protection measures, lack of action to stop rumors, reduced trust in health officials, failure to implement appropriate infection prevention and control measures among healthcare professionals, and cultural differences constitute obstacles to combating COVID-19.

In this article, the strategies to combat the epidemic and the control methods of the current epidemic of COVID-19, and the obstacles that affect the fight against outbreaks are mentioned.
\end{abstract}

Keywords: Control, COVID-19, outbreaks, prevention

1Prof. Dr. Alanya Alaaddin Keykubat Üniversitesi Sağılık Bilimleri Fakültesi Hemşirelik Bölümü, Alanya/Türkiye, E-mail: hayriyeunlu@yahoo.com, Tel:05327407266, ORCID: 0000-0002-8662-7415

${ }^{2}$ Başkent Üniversitesi Ankara Hastanesi Ankara/Türkiye, E-mail: eminecansu32@gmail.com, Tel: 05307971076, ORCID: 0000-0002-6338-9442

Geliş Tarihi: 05 Temmuz 2020, Kabul Tarihi: 03 Ocak 2021

Atıf/Citation: Ünlü H, Çiçek E. Salgın Hastalıklardan Koruma ve Kontrol Önlemleri, COVID-19 Pandemisi ile Mücadele ve Yaşanan Güçlükler Hacettepe Üniversitesi Hemşirelik Fakültesi Dergisi 2021;8(1):101-107. DOI: 10.31125/hunhemsire.907978 


\section{GíRiş}

Enfeksiyon hastalıkları dünya çapında salgınlara, mortalite ve morbiditede artışa sebep olabildiği gibi birçok kişide sakatlık ve işgücü kayıplarına da neden olmuştur. Bu hastalıklar aynı zamanda geri kalmış ve gelişmekte olan ülkelerde erken yaştaki ölümlerin önde gelen nedeni olarak da belirtilmektedir ${ }^{1}$.

Günümüzde mülteciler ve göçmenler dahil nüfusların iç ve uluslararası hareketleri, rastgele ve kontrolsüz şehirleşme, ekonomik gelişme ve arazilerin kullanış şekillerindeki değişiklikler ile oluşan ekolojik ve iklimsel değişiklikler hastalıkların yayılması için yeni fırsatlar yaratmaktadır. Bilim ve teknolojideki gelişmeler ve küreselleşme, hızla artan uluslararası hava ulaşımı, ticaret ve turizm nedeniyle hastalıklar bir kıtadan diğerine hızla yayılmaktadır². Ayrıca gelir dağılımındaki eşitsizlik, bölgesel çatışmalar, yaşam tarzındaki değişiklikler enfeksiyon hastalıkların yayılımını arttırmıştır. Çiçek aşısının bulunması ile çiçek hastalığı gibi bazı bulaşıcı hastalıkları yeryüzünden eradike edilmiştir, ancak AIDS, Ebola, Kırım Konga Kanamalı Ateşi / COVID-19 gibi yeni hastalıklar eradike edilen hastalıkların yerini hızla almıştır ${ }^{1}$. Hiçbir ülke enfeksiyon hastalıklarının yayılımından kendini soyutlayamaz. Bu nedenle enfeksiyon hastalıklarının küresel yayılımına karşı mücadele de küresel olmalıdır. Salgın hastalıkla mücadele bilimsel stratejilerle ve küresel bir dayanışma içinde yürütülmelidir ${ }^{3}$. Küresel salgın kontrolünün sağlanabilmesi, kalıcı ve müdahale edilebilir düzeyde olabilmesi için salgının beraberinde getirdiği; sosyal, kültürel, politik ve ekonomik sorunlara da çözüm aranmalıdır.

Günümüz salgını COVID-19'dan da anlaşılabileceği üzere salgınlar, ülkeler için büyük ekonomik ve aynı derecede yıkıcı sosyal maliyetlere sebep olabilmektedir. Günümüzde COVID-19 için yapılan test sayısı ve test yapılanlar içinde enfekte olan kişi sayısı bilinirken, tüm dünyada COVID -19'a yakalanan yada COVID-19 taşıyıcısı olan kişi sayısı net olarak bilinmemektedir ${ }^{4}$. Hastalığın yayılımını önlemek için alınan tedbirler birçok kişinin çalışma ve sosyal hayata katılamamasına, üretimin azalmasına neden olarak ekonomiyi derinden etkilemiştir. COVID-19 güçlü bir sosyal devlete duyulan gereksinimi açık biçimde ortaya koyarken, diğer yandan da toplumsal bir sağlık sisteminin ne kadar önemli olduğunu da gözler önüne sermiştir. Ülkeler küresel salgınlardan olumsuz etkilenmemek ve/veya etkilerini en aza indirmek için salgın öncesinde, sırasında ve sonrasında koruyucu önlemler almalı, salgınlara her zaman hazırlıklı olmalı ve küresel salgınlarla mücadele edebilmek için stratejik planlar bulundurmalıdırlar ${ }^{5}$.

\section{Amaç}

Bu makalede genel olarak salgın yönetimi ve günümüzde yaşanan COVID-19 ile mücadele kapsamında alınması gereken önlemler ve karşılaşılan engeller ele alınmıştır.

\section{Pandemi ve Eylem Planlarının Önemi}

Dünya Sağlık Örgütü (DSÖ) pandemiyi; dünyada birden fazla ülkede veya kıtada, çok geniş bir alanda yayılan ve etkisini gösteren salgın hastalıklara verilen genel isim olarak tanımlamaktadır. Dünya Sağlık Örgütü’ne göre hastalığa dönüşmüş bir enfeksiyonun pandemi olması şu üç koşulu taşıyor olmasına bağlıdır ${ }^{6}$ :

1. Daha önce maruz kalınmayan bir salgın hastalığın ortaya çıkması.

2. Hastalık etmeninin insanlara bulaşıyor ve tehlikeli bir hastalığa yol açıyor olması.

3. Hastalığı oluşturan etmenin kolay ve devamlı yayılabilir olması.

Dünya Sağıık Örgütü'nün bu maddeleri ışığında, bir hastalık veya durumun yaygın olmasının ve çok sayıda insanın ölümüne yol açmasının pandemi olarak nitelendirilemeyeceği anlaşılmaktadır, çünkü pandemi için hastalığın bulaşıcı olması da gerekmektedir. Örneğin yaygın bir ölüm sebebi olan kanserlerin bazı türleri bulaşıcı etmenler tarafından oluşturulmasına rağmen, kanser bulaşıcı bir hastalık olmadığı için pandemi olarak görülmemektedir ${ }^{7}$. Bir enfeksiyon hastalığı pandemi olarak kabul edildikten sonra, durumu olabildiğince erken ve doğru müdahaleler ile kontrol altına almak önemlidir. Salgın sırasında yerelden küresel seviyelere kadar sorumluluk, yetki ve hesap verebilirlik etkili bir eylem için zorunludur. Eylem planına; sağlık, ulaşım, göç, iletişim, finans, su ve sanitasyon, savunma, barınma ve eğitim alanları da dahil edilmelidir. Zira küresel salgınlar, gündelik yaşam alışkanlıklarından toplumların sosyal, siyasal, ekonomik ve kültürel yapılarına uzanan köklü değişikliklere neden olmaktadır. Günlük yaşamın değişmesi ile birlikte olumsuz psikolojik etkilerin görülmesi ve sağlık sisteminin derinden sarsılması da küresel salgınların sonuçlarındandır. Oluşan bu olumsuz etkiler, erken tespit ve müdahale ile azaltılabilmektedir ${ }^{8,9}$.

Günümüzde COVID-19 pandemisinin ülkemizde de olumsuz sonuçlara yol açtığı görülmektedir. Örneğin COVID-19 nedeniyle pek çok sektörde çalışmalara ara verildiği özellikle hizmetler sektöründe pek çok işletmenin kapandığı ya da faaliyet biçimini değiştirmeye çalıştığı görülmektedir ${ }^{10}$. Uluslararası Çalışma Örgütü (ILO) (2020) Covid-19 salgının emek piyasasında geniş kapsamlı etkileri olacağını bildirmektedir. Buna göre, COVID-19 küresel ölçekte işsizliği artıracaktır. ILO'nun tahminlerine göre iyi senaryoda 5,3 milyon ve kötü senaryoda ise 24,7 milyon yeni işsizden bahsedilmektedir. Salgının olumsuz etkileri sadece işsizliğin artması biçiminde değil, ayrıca çalışan yoksulluğunun artması ve yaygınlaşması biçiminde de tezahür edebilir ${ }^{11}$. Türkiye İstatistik Kurumu'nun, 2020 Nisan ayı ekonomik güven indeksi verilerine göre endeks, nisanda bir önceki aya göre \% 44.1 azalarak 51.3'e gerilemiştir. Ayrıca tüketicinin hizmet sektörüne güven endeksi \%50.1 gerileyerek 46.1'e, perakende ticaret sektörü güven endeksi \% 26 azalarak 75.2'ye, inşaat sektörü güven endeksi \% 42.2 düşerek 44.7'ye gerilemiştir ${ }^{12}$. Aynı şekilde, Acar'ın yaptığı araştırmaya göre turizm sektörü de COVID-19 enfeksiyonundan olumsuz etkilenmiştir ${ }^{13}$.

\section{Salgın Yönetimi}

Salgın yönetiminin öncelikli amacl; morbidite, mortalite ve diğer olumsuz hastalık etkilerini en aza indirmek için salgını mümkün olan en kısa sürede kontrol altına almaktır ${ }^{12}$. 


\section{Salgın anında korunma ve kontrol önlemleri üç boyutta yapılabilir.}

1.Kaynağa yönelik alınabilecek önlemler; kaynağın bulunması, hastalığın bildirilmesi, kesin tanı, hastaların tedavisi, izolasyon, taşıyıcı araması, şüphelilerin sürveyansı, sağlık eğitimi, zoonotik bir hastalıkta hayvanların yok edilmesidir.

2.Bulaşma yoluna yönelik alınabilecek önlemler; Çevre koşullarının düzeltilmesi (sanitasyon, dezenfeksiyon), yiyecek ve içecek maddelerinin denetimi, sağlık eğitimi, kişisel temizlik ve koruyucu ekipman kullanımı, konut koşullarının düzeltilmesi, nüfus hareketlerini kısıtlamaktır.

3.Sağlam kişiye yönelik alınabilecek önlemler; aşılama, seroproflaksi, kemoproflaksi, karantina gözlem, sağlıklı beslenmedir ${ }^{4}$.

Uluslararası yıkıcı salgınlara yol açabilecek tehlikeler konusunda ülkeler potansiyel risk altında bulunmaktadır. Hastalıklara neden olan mikroorganizmaların yayılması, yol açabilecekleri hastalık ve ölümler ile salgın hastalıkların yayılması sonucu, oluşacak panik nedeniyle ağır sonuçlar ortaya çıkabilmektedir ${ }^{5}$.

Salgının erken tespit edilmesi ve müdahale önlemlerinin hızı bir şekilde başlatılması, salgını kontrol etme olasılığını arttırmaktadır. Erken tespit edilen salgın sayesinde aktif vakalar test edilerek bulunur, enfekte kişilerin seyahat geçmişi, kimlerle temas ettiği, temasların karantinası ve enfekte kişilerin izolasyonu izlenir ${ }^{14,15}$.

Bir salgının erken ve geç tespit edilmesinin salgın kontrolüne etkisi şekil 1 ve 2'de verilmiştir. Salgının erken tespiti, bir salgının doğal zirvesine ulaşmasını engelleyerek morbidite ve mortaliteyi büyük ölçüde azaltabilir ${ }^{14}$.

Her salgında bir indeks vakası belirlemek her zaman mümkün değildir; ancak, kaynağı bilinmeyen ateşlerin uygun şekilde araştırılmasıyla vakaları mümkün olduğu kadar erken tespit edilmesi sağlanabilir. Sağlığın korunması ve geliştirilmesi, sağlık iletişimi salgına yönelik girişimlerin ve hazırlıkların entegrasyonunu kolaylaştırmada, yerel düzeyde gerekli işbirliği ve ortaklılığı sağlamada doğal köprüler olabilir ${ }^{14,15}$.

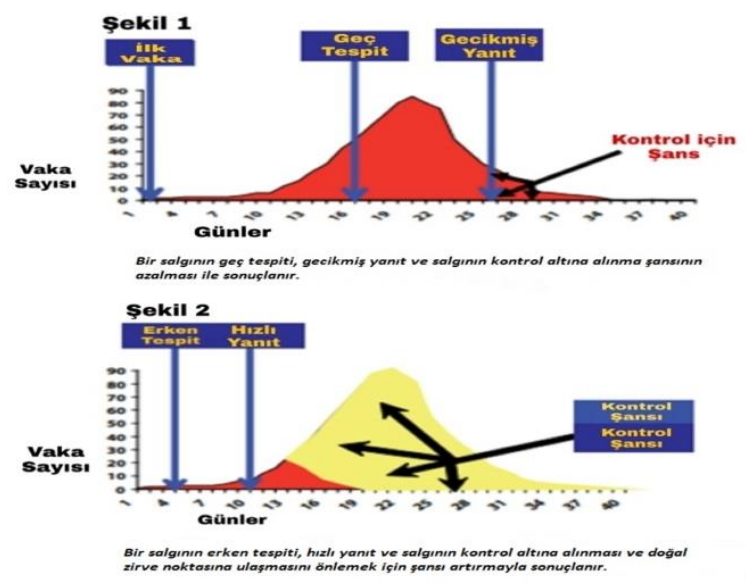

Şekil 1 ve Şekil 2. Bir salgının erken ve geç tespit edilmesinin salgın kontrolüne etkisi ${ }^{14}$
Salgın ve COVID-19

Pandemic and COVID-19

\section{Salgın Hastalıklarda Koruma ve Kontrol Önlemleri}

Küresel Uyarı ve Yanıt Ağı'nın (The Global Alert and Response Network) 2003'te yayınladığı bulaşıcı hastalıkların tehdidine karşı küresel önlemler kitapçığında, salgınla mücadele ve yanıtta üç aşamalı yaklaşım önerilmektedir. Birinci aşama salgına sebep olabilecek mevcut riskleri bilmek, ikinci aşama beklenmedik durumlara ve hastalıklara karşı hızlı cevap vermek ve son aşama küresel çapta oluşabilecek salgınlara karşı daima hazırlıklı olup gelişmeleri takip etmektir ${ }^{16}$.

Ghebrehewet ve Stewart, (2016) salgının sistematik olarak yönetilebilmesi için profesyonellerin ve kuruluşların; salgının niteliğini ve kapsamını belirlemesi gerektiğini, iç ve dış iletişimi etkin bir şekilde yönetmeleri, geçmişte yaşanan benzer salgınlardan gelecekteki salgınları önlemeye yönelik dersler çıkarmaları, salgın yönetiminde güncel teknolojiyi kullanmaları, ortaya çıkan yeni organizmaların niteliğini ve yayılımını iyi anlamaları, kamusal endişeleri hafifletmeleri gerektiğini vurgulamışlardır ${ }^{17}$.

Salgına uygun koruma ve kontrol önlemlerinin alınması ve etkililiğinin takibi salgın süresince ve sonrasında yapılmalıdır. Salgının incelenmesi ve kontrol önlemlerinden hangisinin daha önce başlatılacağına karar verilirken etken, kaynak ve bulaşma yolunun tespit edilmesi önemlidir. Salgının etkeni bilinmiyor ancak kaynak/bulaşma yolu biliniyorsa; kontrol önlemleri ve salgın incelemesi aynı anda başlatılmalıdır. Koruma ve kontrol önlemleri kapsamında salgının özelliğine göre alınacak tedbirler: İlgili sektörlerle işbirliğinin yapılması, risk oluşturan etkenlerin uzaklaştırılması (gıdanın tüketiminin engellenmesi, gerekirse toplatılması, vektör kontrolü, kimyasal etkenlerin risk oluşturacak yayılımının engellenmesi vb.), kontamine su kaynaklarının kullanımının engellenmesi ve suyun klorlanması, hasta izolasyonu, temaslılara müdahale edilmesi, riskli grupların aşılanması, sağlık personelinin eğitimi ve halk sağlığı eğitimini kapsamaktadır ${ }^{18-20}$.

Dünya Sağlık Örgütü'nün salgında davranışsal ve sosyal iletişim rehberine göre salgın müdahale stratejisinin ana bileşenleri Tablo 1'de verilmiştir ${ }^{14}$.

\section{Tablo 1. Salgın Müdahale Stratejisinin Ana Bileşenleri}

Davranışsal ve Sosyal Müdahaleler

- Hanehalkı ve toplum düzeyinde risk azaltma önlemlerinin belirlenmesi

- Iilgili, teknik olarak uygulanabilir, etkili, sosyal ve kültürel olarak kabul edilebilir topluluk müdahalelerinin tasarımının yapılması

- Çeşitli yaklaşımların kullanımı, örn. sosyal mobilizasyon, sağlık eğitimi ve tanıtımı, riski azaltmak ve daha fazla hastalık bulaşmasını durdurmak için önlemlerin alınmasının teşvik edilmesi 
Tablo 1. Salgın Müdahale Stratejisinin Ana Bileşenleri (devamı)

Klinik Bakım
- Vaka ölüm oranının azaltılması ve uygun hasta bakımı ile
- $\quad$ Enfastığın daha fazla yayılmasının önlenmesi
Medya İletişimi
- $\quad$ Medya iletişim planının geliştirilmesi
- $\quad$ En uygun kanallar aracılığıyla zamanında sağlık bilgilerinin
sağlanması
Kamuoyunun endişelerinin tespit edilmesi ve bu
endişelere saygı duyulması
- Sözcülerin ve gazetecilerin eğitilmesi
Operasyonel müdahalenin güven ve inanılırlığının
sağlanması ve sürdürülmesi
Lojistik ve Güvenlik
Ekip üyelerinin güvenlik önlemlerine uygun çalışmalarının
sağlanması
Epidemiyolojik Araştırma ve Laboratuvar Testleri
- $\quad$ Enfeksiyonun ve bulaşma yolunun tanımlanması
Etkili kontrol önlemlerinin belirlenmesi
Doğru ve hızlı tanı yöntemlerinin sağlanması

\section{Salgın Yönetimi ve Mücadelesi Kapsamında COVID- 19 Pandemisi}

Coronavirüs ailesinin en son bulunan, hayvanlarda ve insanlarda hastalığa neden olan üyesi COVID-19'dur. Bu yeni virüs ve hastalık, Aralık 2019'da Çin'in Wuhan kenti Güney Çin Deniz Ürünleri Şehir Pazarı (farklı hayvan türleri satan bir toptan balık ve canlı hayvan pazarı) çalışanlarında etiyolojisi bilinmeyen pnömoni vakaları bildirilmesiyle ortaya çıkmıştır ve şu anda küresel olarak birçok ülkeyi etkileyen salgın bir hastalıktır. COVID-19 enfeksiyonunda en sık olarak görülen belirtiler; ateş, kuru öksürük ve yorgunluktur. Daha ağır vakalarda ise nefes darlığı, göğüs ağrısı veya göğüste basınç hissi, konuşma, hareket kaybı ile birlikte ateş ve / veya öksürük görülebilmektedir ${ }^{21}$. Yayılım insandan insana öksürme hapşırma veya konuşma sırasında atılan küçük damlacıklar yoluyla olmaktadır. Aynı zamanda bu damlacıklar yüzeylerin üzerine düşerek enfeksiyon için risk oluşturur. İnsanlar bu virüslü yüzeylere dokunup ardından ağız, burun veya gözlerine dokunarak da enfekte olabilmektedirler ${ }^{22}$.

Dünya Sağlık Örgütü’nün 15 Aralık 2020 verilerine göre tüm dünyada doğrulanmış vaka sayısı 71.581 .532 olup, 1.618.374 kişi bu hastalık nedeni ile hayatını kaybetmiştir. COVID-19'a bağlı ölümlerin en çok görüldüğü bölge 30.656.971 kişi ile Amerika iken en az ölümün görüldüğü bölge 971.624 kişi ile Batı Pasifiktir ${ }^{23}$. Ülkemizde ise 15 Aralık 2020 verilerine göre onaylanmış vaka sayısı 1.052.007 ve ölüm sayısı $16.6466^{\prime}$ ır $^{24}$. Amerika Birleşik Devletleri Hastalık Kontrol ve Önleme Merkezleri' ne (Center for Disease Control and Prevention (CDC) göre COVID-19'a bağı ölümler en çok, yaşlı yetişkinlerde ve altta yatan ciddi tıbbi rahatsızıkları olan herhangi bir yaştaki kişilerde görülmektedir. Riskli bireyleri ve toplumu korumak için COVID-19 ile mücadele önemli yer tutmaktadır ${ }^{25}$.

\section{COVID-19 ile Mücadele}

Dünya Sağlık Örgütü, Mart 2020'de COVID-19 salgınına ilişkin yayınladığı rehberde COVID-19 ile mücadelenin amacını; salgını yavaşlatma ve durdurma, yayılımı önleme ve geciktirme, tüm hastalar ve özellikle ağır hastalar için optimize edilmiş bakım sağlama, salgının sağlık sistemleri, sosyal hizmetler ve ekonomik faaliyetler üzerindeki etkisini en aza indirme olarak açıklamıştır. Bütün bu amaçları gerçekleştirebilmek için ülkelerin kapsamlı önlem paketine ihtiyaçları vardır ve bu önlem paketinin içeriği ülkenin veya ulusun salgında hangi senaryo ile karşı karşıya olduğuna bağlı olarak değişmektedir 26 .

Mücadele kapsamındaki önlemler ve eğitimler on başlık altında gruplandırılmıştır ${ }^{27}$ :

1. Ulusal Koordinasyon Sağlama

2. Risk İletişimi Oluşturma ve Toplum Katılımı Sağlama

3. Halk Sağlığı Önlemleri

4. Vaka ve Sağıık Hizmetleri Yönetimi

5. Enfeksiyonun Önlenmesi ve Kontrolünün Sağlanması

6. Sürveyans, Risk ve Şiddet Değerlendirmelerinin Yapılması

7. Ulusal Laboratuvar Sistemlerinin Geliştirilmesi

8. Lojistik ve Tedarik Yönetimi

9. Temel Hizmetlerin Bakımının Sağlanması

10. Araştırma ve Geliştirme Çalışmalarının Yapılması

COVID-19 için halihazırda geliştirilmiş bir tedavi yöntemi veya etkinliği kanıtlanmış bir aşı bulunmamaktadır. Bu nedenle bulaşmayı azaltmak için alınan önleme ve kontrol stratejileri halk sağlığı önlemlerine dayanmaktadır. Bu önlemler, kişisel koruyucu önlemler, çevresel önlemler, sosyal uzaklaşma ve seyahatle ilgili önlemleri içermektedir $26,27,28$. Dünya Sağlık Örgütü tarafından her durumda önerilen halk sağlığı önlemleri; el hijyeni, solunum hijyeni, semptomatik bireyler için maske kullanımı, hasta bireylerin izolasyonu ve tedavisi, sağlıklı kişilerin temas belirtilerinin izlenmesi, yolcular için sağlık tavsiyeleri ve çevre temizliğidir. Ülkenin veya ulusun salgın durumuna bağlı olarak önerilen önlemler ise; kalabalıktan kaçınma, okulları kapatma, toplu taşımaları kapatma ve/veya işyerlerini kapatma, halk sağlığı karantinası (asemptomatik temaslılar için) ve/veya izolasyon (hasta kişiler için) önlemleridir 29,30. Önerilen bu uygulamalara karşın farklı ülkeler salgının kontrol altına alınması için farklı önlemler uygulamıştır. Middelburg ve Rosendall Mayıs 2020'de yaptıkları çalışmada hükümetlerin uyguladığı bu farklı önlemleri ele alarak ülkelerin COVID-19 ile mücadelesini karşılaştırmıştır. Çalışmada ülkeler, ilk ölüm tarihine göre senkronize edildikten sonra her ülke için 25.günde toplam ölüm sayısının yüzdesi alınarak pandeminin başladığı Çin ile karşılaştırılmıştır ve bu karşılaştırma sonucunda ülkeler üç kategoriye ayrılmıştır. Birinci kategorideki ülkeler Çin'e benzer bir politikaya sahip olan ülkelerdir. Bu kategorideki ülkeler virüs toplumda önemli ölçüde yayıldıktan sonra önleyici tedbirler alan ülkelerdir, örneğin İtalya, İspanya, Fransa, İngiltere gibi Avrupa ülkeleri. İkinci kategorideki ülkeler, Güney Kore'ye benzer bir politikaya sahip olan yani virüs popülasyonda önemli ölçüde yayılmadan önce katı önleyici tedbirler alan ülkelerdir. Üçüncü kategorideki ülkeler ise ABD gibi çok sayıda ölüm gerçekleşene kadar önleyici tedbirlerin alınmadığı ülkelerdir. Çalışma sonucunda önleme stratejilerinin erken benimsenmesinin 
salgının eğrisini düzleştirmede anahtar olduğu doğrulanmıştır ${ }^{31}$.

\section{COVID-19 ile Mücadelede Zorluklar}

COVID-19 ile mücadelede; toplumla ilişki kurmak, korkuları, engelleri, endişeleri ele almak koruyucu davranışları teşvik etmekte ve kişilerin virüs ile olan mücadeleye doğrudan katılmalarına izin vermektedir. Dünya Sağıık Örgütü'nün COVID-19'a yönelik tespit, önleme, yanıt ve kontrol yöntemlerini açıkladığı online kursunda mücadelede karşılaşılan ve ele alınması gereken engeller şöyle sıralanmıştır ${ }^{32}$ :

- Müdahale ekiplerinin, toplum uygulamalarını, endişelerini ve korkularını anlama eksikliği,

- Hastalık ve müdahale hakkında yavaş / geç bilgi vermenin toplumda endişeyi ve salgının hızını arttırması,

- Korunma önlemleri hakkında bilgi ve farkındalık eksikliği nedeni ile hastalığın yayılımının şiddetlenmesi,

- Toplumsal anlaşma olmadan önlemlerin uygulanmaya başlanması, toplumsal kabulün geç olması,

- Söylentileri durdurmak için geç / hiçbir önlem alınmaması, yanlış anlamaların arttırması ve sağlık yetkililerine güvenin azaltması ve bu durumun "tehlikeli" davranışlara yol açması,

- Sağlık çalışanları arasında uygun enfeksiyon önleme ve kontrol önlemlerinin uygulanmaması,

- Bakım ile ilgili kültürel uygulamaların salgının kontrolünü zorlaştırması, örneğin, bazı kültürlerde birçok akraba, hastanedeki hasta aile üyelerine eşlik etmek, onlara yemek getirmek veya onları ziyaret etmek ister. Türkiye için kültürel uygulamalara örnek verecek olursak; Hac'dan gelenleri ziyaret etme, asker yollama seremonisi, bayram ziyaretleri ve el öpme, dügünler, sarılarak selamlaşma, yaz aylarında kalabalık ortamlarda piknik yapmayı sayabiliriz.

- Sağlık hizmeti arama davranışı ile ilgili kültürel uygulamaların salgının kontrolünü zorlaştırması, örneğin, bazı hastalar nerede bakılacaklarına karar vermeden önce birçok farklı hastaneye gidebilirler (buna doktor veya hastane alışverişi denir).

Bütün bu faktörler COVID-19'un toplumda yayılım hızını arttırabilir.

COVID-19 ile Mücadelede Hemşirelerin Yaşadığı Zorluklar

Türk Hemşireler Derneği'nin Temmuz 2020'de yayınlanan COVID-19 Pandemi Süreci adlı makalesinde hemşirelerin yaşadığı zorlukları şu şekilde sıralanmıştır ${ }^{33}$ :

- Yeterli ve kaliteli kişisel koruyucu ekipmanlara ulaşmada zorluk,

- Çalışma koşullarına ve ortamına yönelik sorunlar (24 saate varan uzun çalışma saatleri, yetersiz dinlenme süreleri, dinlenme alanlarının standartlara uygun olmaması ve/veya yetersiz olması/olmaması, çalışma saatlerinde yeterli ve dengeli beslenememe),
- Hemşirelerin çoğunluğunun bulaş riski nedeniyle evlerine gidememesi, çocuk bakımı, kalacak yer temini ve ulaşım konusunda sıkıntı yaşaması,

- Bakım vermekte oldukları hastaların kaybı yanı sıra hem kendileri hem de yakınlarının sağlığına yönelik endişe, kaygı ve korku yaşama,

- COVID-19 salgını nedeniyle mevcut kliniklerin kapatılması, pandemi klinikleri ve hastaneleri oluşturulması sonucunda hemşirelerin deneyimli olmadıkları farklı birimlerde çalışmak zorunda kalmaları,

- Rutin uygulamalarda değişiklik yapılması, bazı işlemlerin kim tarafından yapılacağına yönelik karmaşa olması, enfekte olma korkusu yaşayan diğer sağlık çalışanlarının hasta ile temas gerektiren işlemleri hemşirelere yaptırmak istemesi,

- Pandemi sürecinde hemşireler, ek ödeme, zorunlu ücretsiz izin kullandırma, fazla mesainin karşılığını alamama gibi özlük haklarına yönelik sorunlar da yaşamışlardır.

Bütün bu zorluklar hemşireleri olumsuz etkilemiştir. Hemşirelerin kritik rollerini ortaya koyabilmeleri ve olumsuz etkilerden kurtulabilmeleri için karar alma süreçlerinde etkili rol almaları; liderlik pozisyonlarında daha fazla hemşireye yer verilmesine yönelik girişimlerin yapılması gerekmektedir. Bununla birlikte hem COVID-19 kliniklerinde hem de diğer kliniklerde bakım hizmetlerinin güvenli hastahemşire oranlarını sağlayacak şekilde düzenlenmesi, hemşirelerin çalışma çizelgelerinin hasta ve çalışan ve güvenliğini sağlayacak şekilde planlanması ve uygulanması, fiziki koşulların düzenlenmesi, yeterli malzeme, koruyucu ekipman sağlanması gerekmektedir 33,34.

\section{SONUÇ ve ÖNERILER}

Bulaşıcı hastalıklar ve salgın ile mücadelede koruyucu sağlık hizmetleri yaşamsal bir öneme sahiptir ve erken tanı ile önlemlerin hızlı bir şekilde başlatılması, salgını kontrol etme imkanını arttırmaktadır. Kontrolün kalıcı ve müdahale edilebilir düzeyde olabilmesi için salgının beraberinde getirdiği; sosyal / kültürel sorunlara (salgın dini gelenekleri ve geleneksel inançları uygulamayı engelliyor mu?, vb.), politik sorunlara (hangi etnik ve kültürel grup daha çok etkilendi? Yerel halk yetkililere ne kadar güveniyor? Sağlık personelleri ve yönetim arasındaki ilişki nasıl?, vb.) ve ekonomik sorunlara da çözüm aranmalıdır, çünkü salgınlar COVID-19'dan da anlaşılabileceği üzere ülkeler için büyük ekonomik ve aynı derecede yıkıcı sosyal maliyetlere sebep olabilir. Bu yıkımlar karşısında insanların davranış ve tutumları salgın riskini daha da artırmaktadır. Bu nedenle toplum davranışlarını anlamak, hastalığın bulaşmasını hafifleterek, hastalığı önleme ve kontrol etmede etkili yollar bulmaya yardımcı olabilir. Ayrıca salgına yönelik koruyucu ve önleyici müdahalelerinin bütün halka eşit olarak, demokratik ve bilimsel yöntemler ile sağlanması da oldukça önemlidir.

Çıkar Çatışması: Bildirilmemiştir.

Finansal Destek: Yoktur.

Yazar katkıları:

Araştırma Dizaynı: HÜ, EÇ 
Literatür Tarama: HÜ, EÇ

Makale Yazımı: HÜ, EÇ

Confict of Interest: Not reported.

Funding: None.

Author contributions:

Study Design: HU, EC

Literature Search: HU, EC

Drafting manuscript: HÜ, EC

\section{KAYNAKLAR}

1. Nakajima H. Message from the director-general. The World Health Report Conquering Suffuring Enriching Humanity [internet]. 1997. [Erişim tarihi: 26/06/2020]. Erişim adresi : https://www.who.int/whr/1997/en/.

2. Nakajima H. Message from the director-general. The World Health Report - Fighting Disease Fostering Development [Internet]. 2016. [Erişim tarihi 27/06/2020]. Erişim adresi: https://www.who.int/whr/1996/en/

3. Brundtland GH. Message from the director-general The World Health Report - Reducing Risks, Promoting Healthy Life [Internet]. 2002. [Erişim tarihi 27/06/2020] Erişim adresi: https://www.who.int/whr/2002/en/

4. WHO. Key planning recommendations for mass gatherings in the context of COVID-19 [Internet]. 2020. [Erişim tarihi: 06/12/2020]. Erişim adresi: https://apps.who.int/iris/bitstream/handle/10665/3 32235/WHO-2019-nCoV POE_ mass _gathering2020.3-eng. pdf? sequence $=1 \&$ isAllowed=y

5. Türk Tabipleri Birliği COVID-19 Danışma ve İzleme Kurulu. COVID-19 Pandemisi İki Aylık Değerlendirme Raporu. Türk Tabipleri Birliği [Internet]. 2020. [Erişim tarihi: 04/12/2020]. Erişim adresi : https://www.ttb.org.tr/kutuphane/covid19rapor.pdf

6. COVID-19 Pandemi Değerlendirme Raporu. Türkiye Bilimler Akademisi (TÜBA Raporları No:34) [Internet]. 2020. [Erişim tarihi 10/12/2020]. Erişim adresi: http://www.tuba.gov.tr/files/images/2020/kovidrap oru/Covid-19 Raporu-Final+.pdf

7. Aslan R. Tarihten Günümüze Epidemiler, Pandemiler ve Covid-19. Göller Bölgesi Aylık Ekon ve Kültür Derg. 2020;8(85):35-41.

8. Smith RD. Responding to global infectious disease outbreaks: Lessons from SARS on the role of risk perception, communication and management. Soc Sci Med. 2006; 63 (12) :113-23.

9. Water GLAAS findings on national policies, plans, targets and finance in Treadıng Water Corporate Responses to Rising Water Challenges. Disclosure Insıght's CDP Global Water Report [Internet]. 2018. [Erişim tarihi 14.04.2020]. Erişim adresi : https://www.who.int/water_sanitation_health/publ ications/hygiene-glaas-findings/en/

10. Özatay F, Sak G. COVID-19'un Ekonomik Sonuçlarını Yönetebilmek İçin Ne Yapılabilir? Türkiye Ekon Polit Araştırma Vakfı [Internet]. 2020. [ Erişim tarihi
Salgin ve COVID-19

Pandemic and COVID-19

10.05.2020]. Erişim adresi https://tepav.org.tr/upload/files/1585023057-

6.Covid_19un_Ekonomik_Sonuclarini_Yonetebilmek _Icin_Ne_Yapilabilir.pdf

11. Akbağ, E. Covid 19'un Toplumsal etkileri; Kovid-19 ve Sonrası: Disiplinlerarası Bir Yaklaşım: Halk Sağlığı, Hukuk, iktisat, illahiyat, Psikoloji, Sosyoloji, Tıp. Uluslararası İlişkiler ve Stratejik Araştırmalar (ULiSA) Enstitüsü [Internet]. 2020. [Erişim tarihi 16/12/2020]. Erişim adresi: https://aybu.edu.tr/yulisa /contents /files /ULI\%CC\%87SA_12_3_Haziran_2020(1).pdf

12. 12.Türkiye İstatistik Kurumu. Ekonomik Güven Endeksi, 33928 Nisan [Internet]. 2020. [Erişim tarihi: 26.06. 2020]. Erişim adresi : http: //www.tuik.gov.tr/ Pre Haber Bultenleri. do?id=33928

13. Acar Y. Yeni Koronavirüs (COVID-19) Salgını ve Turizm Faaliyetlerine Etkisi. Güncel Tur Araştırmaları Derg. 2020;4:7-21.

14. World Health Organization. Communication For Behavioural Impact (COMBI) [Internet]. 2020. [Erişim tarihi 28/11/2020]. Erişim adresi: https://apps. who.int/iris/ bitstream/handle/10665/75170/WHO_HSE_GCR_20 12.13_eng.pdf

15. Madurai ER, Pugazhendhi R. Restructured society and environment: $A$ review on potential technological strategies to control the COVID-19 pandemic. Sci Total Environ. 2020;725: 138858

16. Global Defence Against the Infectious Disease Thereat. World Health Organization [Internet]. 2003. [Erişim tarihi: 10.06.2020]. Erişim adresi: https://apps.who.int/iris/

bitstream/handle/10665/42572/9241590297.pdf;js essionid=AA636C7EFE7BC628E7C0399F63AA419D?s equence $=1$

17. Ghebrehewet S, Stewart AG. Incidents and outbreak management. (Edi: Ghebrehewet S, Stewart AG, Baxter D, Shears P, Conrad D, Kliner M) Health Protection: Principles and Practise. Oxford University Press; 2016. Available at: https://books.google.com.tr/books?id=SsBjDQAAQB AJ\&dq=Taking+Outbreak+Protection+and+Control+ Measures\&hl=tr

18. Bulaşıcı Hastalıklar ile Mücadele Rehberi. Halk Sağlığı Genel Müdürlüğü [Internet]. 2017. [Erişim tarihi: 28.04.2020]. Erişim adresi : https://hsgm.saglik. gov.tr /depo/ mevzuat/genelge/Bulasici_Hastaliklar_ile_Mucadele _Rehberi_Ustyazi.pdf

19. Sıkça Sorulan Sorular [Internet]. Covid-19 Türkiye Web Portalı [Internet]. 2020. [Erişim tarihi: 02.07.2020]. Erişim adresi : https://covid19.tubitak.gov.tr/covid19/sikca-sorulan -sorular

20. Halk Sağlığı Genel Müdürlüğü. Pandemik Influenza Ulusal Hazırık Planı. T.C. Sağlık Bakanlığı [Internet]. 2020. [Erişim tarihi: 01.06.2020]. Erişim adresi: 
https://grip.gov.tr/depo/saglik-

calisanlari/ulusal_pandemi_plani.pdf

21. Kenney SP, Helmy YA, Fawzy M, Elaswad A, Sobieh A, Shehata AA. The COVID-19 Pandemic: A Comprehensive Review of Taxonomy, Genetics, Epidemiology, Diagnosis, Treatment, and Control. J Clin Med. 2020;9(4):2-29

22. World Health Organization. Q\&As on COVID-19 and related health topics and on coronaviruses (COVID19) [Internet]. 2020. [Erişim tarihi: 06.06.2020]. Erişim adresi : https://www.who.int/emergencies/diseases/novelcoronavirus-2019/question-and answers-hub/q-adetail/q-a-coronaviruses

23. WHO Coronavirus Disease (COVID-19) Dashboard. World Healh Organization [Internet]. [Erişim tarihi: 2020 28.05.2020]. Erişim adresi : WHO Coronavirus Disease (COVID-19) Dashboard | WHO Coronavirus Disease (COVID-19) Dashboard

24. World Heath Organization. Coronavirus Disease Situation Report-138 [Internet]. 2020. [Erişim tarihi: 18.08.2020]. Erişim adresi: https://www.who.int/docs/default-source/ coronaviruse/situation-reports/20200606-covid-19sitrep-138. pdf?sfvrsn =c 8ab fb17_4

25. Centers for Disease Control and Prevention. Higher Risk [Internet]. 2020. [Erişim tarihi :11.12.2020]. Erişim adresi: https:// www.cdc.gov/ coronavirus/ 2019-ncov/faq.html\# Higher-Risk

26. World Healh Organization. Controlling the spread of COVID-19 at ground crossings [Internet]. [Erişim tarihi: 23.06.2020]. Erişim adresi : https://apps.who. int/iris /bitstream /handle/10665/332165/WHO2019-nCoV-Ground_crossings-2020. eng. pdf? sequence $=1 \&$ isAllowed $=y$

27. World Health Organization. Responding to Community Spread of COVID-19 [Internet]. 2020. [Erişim tarihi: 05.06.2020. Erişim adresi: https://apps.who.int/iris/handle/ 10665 /331421

28. Shih H-I, Wu C-J, Tu Y-F, Chi C-Y. Fighting COVID-19: A quick review of diagnoses, therapies, and vaccines. Biomedical Journal [Internet]. 2020. [Erişim tarihi: 18.06.2020]. Erişim adresi: https://reader.elsevier.com/reader/sd/pii/S231941 7020300858?token= 4A5021C1C80D0CF03BB85DAFA2E9D9F2B78D1ACB 40437460BCEE6636FCF190DC0172B30227C23AE1D FBBFF1E049A96F2

29. World Healh Organization. Advice on the use of masks in the context of COVID-19 [Internet]. 2020. [Erişim tarihi: 01.08.2020]. Erişim adresi: file://C:/Users/x/ Downloads/ WHO-2019-nCovIPC_Masks-2020.4-eng.pdf

30. World Healh Organization. Infection prevention and control during health care when novel coronavirus ( $\mathrm{nCoV}$ ) infection is suspected: interim guidance [Internet]. 2020 . [Erişim tarihi: 15.12.2020]. Erişim adresi : https://apps.who.int/iris/rest /bitstreams/ $1272420 /$ retrieve
31. Middelburg, R. A. and Rosendall FR. COVID-19: How to make between-country comparisons. Int J Infect Dis. 2020;96:477-81.

32. World Health Organization. Emerging respiratory viruses, including COVID-19: methods for detection, prevention, response and control [Internet]. 2020. [Erişim tarihi: 20.06.2020]. Erişim adresi: https://open.who.org/courses/introduction-to ncov/ items/ 6FTk2sMdJ6uzXqINC14hG132.

33. Şenol Çelik S, Atlı Özbaş A, Çelik B, Karahan A, Bulut $\mathrm{H}$, Koç G, et al. COVID 19 Pandemic Process: Turkish Nurses Association. J Educ Res Nurs. 2020;17(3):27983.

34. Duygulu S, Başaran Açıl S, Kuruca Özdemir E, Erdat Y. COVID-19 Salgını: Yönetici Hemşirelerin Rol ve Sorumlulukları. Hacettepe Üniversitesi Hemşirelik Fakültesi Derg. 2020;7:34-46. 